\title{
EFFECTS OF QUANTITY AND LAYERS NUMBER OF LOW TRANS MARGARINES ON PUFF PASTRY QUALITY
}

\author{
Jana J. Zahorec*, Dragana M. Šoronja-Simović ${ }^{1}$, Zita I. Šereš ${ }^{1}$, Olivera D. Šimurina ${ }^{2}$, Anastasija I. \\ Selaković $^{3}$, Nikola R. Maravić ${ }^{1}$, Bojana V. Filipčev ${ }^{2}$ \\ ${ }^{1}$ University of Novi Sad, Faculty of Technology, 21000 Novi Sad, \\ Bulevar cara Lazara 1, Serbia \\ ${ }^{2}$ University of Novi Sad, Institute of Food Technology, 21000 Novi Sad, \\ Bulevar cara Lazara 1, Serbia \\ ${ }^{3}$ MiniPani doo, 24000, Subotica, Hipodromska bb, Serbia
}

\author{
*Corresponding author: \\ Phone: +381214853663 \\ Fax: +38121450314 \\ E-mail address: jana.zahorec@tf.uns.ac.rs
}

\begin{abstract}
The aim of this study was to investigate the effect of puff pastry margarine with reduced content of trans isomers in production of puff pastry with enhanced nutritional value. Experiments were carried out on the basis of $3^{2}$ factorial design, wherein the independent variables were the amount of puff pastry margarines (30, 40 and $50 \%$, on flour weight) and number of margarine layers formed during the dough processing $(108,144$, and 256). In order to determine the optimum values of independent parameters, the study was focused on defining of relevant qualitative indicators of the final product.

By investigation of influence of the type of puff pastry margarine (ML1 and ML2) on the quality of puff pastry, it was determined that physico-chemical properties of margarine ML1 were not optimal for puff pastry production. Margarine ML1 had lower hardness by $50-60 \%$, lower SFC by $20-35 \%$ and worse thermal characteristics compared to margarine ML2. Only by application of the maximum amount of margarine ML1 and 144 margarine layers a satisfactory quality of puff pastry was obtained: the lift of 2.89 , hardness of $17.7 \mathrm{kgs}$, volume $83.6 \mathrm{~cm}^{3}$ and the total number of points of 14.8 . Because of its better technological characteristics, margarine ML2 is favorable for making puff pastry. Significantly better physical properties and excellent pastry quality was obtained in samples with margarine ML2 in an amount of $50 \%$ of margarine and 256 layers: higher lift by $45 \%$, volume by $25 \%$ and the total number of points by about $20 \%$ compared to sample ML1 with the best quality.
\end{abstract}

Key words: trans fatty acids, puff pastry, sensory quality, textural properties

\section{INTRODUCTION}

Characteristic properties of puff pastry are airy-flaky structure and excellent sensory characteristics. Due to the specific structure, any errors can have far greater consequences on the quality of puff pastry in regards to the majority of other bakery products. The most common causes of bad puff pastry quality are: inadequate quality of raw materials (flour or puff pastry fat), mistakes made during dough processing (inadequate number of dough lami- nation and folding) and errors during baking (Šoronja-Simović, 2012).

The puff pastry margarines have a key role in separating dough layers and preventing their coalescence during lamination. Physical properties (consistency) of puff pastry fats have a significant effect on the formation of dough layers and thereby the lift and the structure of final product. Puff pastry fats must possess the appropriate plastic properties in order to main- 
tain uniform layers during lamination and pressure of water vapor during baking (McGill, 1981). The fact that the differences of special-purpose margarines and dough consistency can have a significant negative effect on puff pastry quality indicates that it is necessary to define their physical and thermal properties.

Nowadays, there is a possibility to modify the physical characteristics and to adjust the composition of puff pastry margarines to the nutritional requests by innovation of the existing and development of new processes of margarine production (Laia et al., 2000; Kritchevsky, 2008). Moreover, in accordance with the requirements of the World Health Organization (WHO, 2003) to reduce the intake of trans fatty acids (TFA) to less than $1 \%$ of daily energy needs, the margarines with a reduced content of trans-isomers are obtained.

The negative effect of TFA on health is the result of a several complex and related phenomena. According to some epidemiological studies, the reduction of the total and HDL (high-density lipoprotein) cholesterol ratio caused by TFA is about twice as high compared to the atherogenic effects of saturated fatty acids - lauric, myristic and palmitic (Aro, 2006).

The examinations of puff pastry margarines with reduced content of TFA suggest that there are differences in their physicochemical properties, and that the share of trans fatty acids cannot be the only valid parameter in the selection of a margarine for making puff pastry with improved nutritional quality.

From the wide range of margarines with reduced TFA content, it is necessary to select those in which the changes in composition of the fat phase have not negatively affected their technological characteristics (Šoronja Simović, 2010).

The aim of this work was to investigate the effects of quantity and layers number of low trans margarines with different physicchemical and textural characteristics on the production of puff pastry with enhanced nutritional value based on the results for physical and sensory characteristics of puff pastry.

\section{MATERIALS AND METHODS}

The examinations were conducted on a sample of wheat flour T-400 from the regular production of JSC "Danubius", Novi Sad. The quality of flour, i.e., moisture, protein content and water absorption (by farinograph) was defined according to the standard procedures AACC 44-19, 46-12 and 54-21, respectively (AACC, 1995). Wheat flour used in the experiments had the following chemical characteristics: moisture $13.9 \%$, protein content $11.5 \%$ (on dry matter content) and water absorption determined by Brabender farinograph $54.8 \%$. The basic dough consisted of the following additional materials: common salt, margarine for kneading (in-dough fat) ("Dijamant", Zrenjanin, Serbia) and additive ("Biser", Novi Sad, Serbia). Two samples of puff pastry margarine with $70 \%$ fat phase and reduced content of trans fatty acids were used as a roll-in fat for pastry production: margarine ML1 ("Dijamant", Zrenjanin, Serbia) and margarine ML2 ("Puratos", Beograd, Serbia).

\section{Fatty acid composition}

The fatty acid composition of puff pastry margarine was determined by standard method ISO 15304 (2002), which includes the usage of a gas chromatographic method for separation and a mass spectrometry for the identification of individual components of the mixture. The determination was carried out on a gas chromatograph Hewlett Packard 5890A and mass spectrometer Hewlett Packard 5971 with a capillary column SP-2560, length $100 \mathrm{~m}$, inner diameter of $0.25 \mathrm{~mm}$ and the stationary liquid phase film thickness of 0.20 $\mu \mathrm{m}$.

\section{Solid fat content}

The solid fat content (SFC) is determined by the standard method ISO 8292-1 (2008a) using the pulsed nuclear magnetic resonance (NMR) method on Bruker minispec 20 mq NMR device.

\section{Thermal characteristics}

The thermal properties of the margarine samples were examined by using a differential scanning calorimeter (DSC) Q20 TA Instruments. Flow of the inert gas 
(nitrogen) during the examination was 50 $\mathrm{cm}^{3} / \mathrm{min}$. The measurement was carried out at temperature range from $25^{\circ} \mathrm{C}$ to 60 ${ }^{\circ} \mathrm{C}$ at a heating rate of $5{ }^{\circ} \mathrm{C} / \mathrm{min}$. The weight of the examined samples was 13 mg. Standard calibration of instrument was performed using indium $\left(\mathrm{Tm}=156.6{ }^{\circ} \mathrm{C}\right)$. Based on the obtained DSC data, the melting enthalpy $(\mathrm{J} / \mathrm{g})$, as well as the melting temperature were determined for the two samples.

\section{Physical characteristics}

Hardness of puff pastry margarines was determined using the penetration method of cylinder probe with diameter of $5 \mathrm{~mm}$ at temperatures of $10,20,25$ and $30{ }^{\circ} \mathrm{C}$ on the Texture Analyzer TA.HDPlus by the following operating parameters: load cell $5 \mathrm{~kg}$, cylinder probe speed before analysis - $1.0 \mathrm{~mm} / \mathrm{s}$, cylinder probe speed during the analysis - $2.0 \mathrm{~mm} / \mathrm{s}$, cylinder probe speed after analysis - $2.0 \mathrm{~mm} / \mathrm{s}$ and distance - $12 \mathrm{~mm}$.

\section{Puff pastry production}

Investigation was carried out on the basis of $3^{2}$ complete factorial design, wherein the two independent variables were the amount of puff pastry margarine and the number of fat layers.

The basic dough was prepared according to formula: $1000 \mathrm{~g}$ of flour, $2 \%$ salt, and $5 \%$ margarine for kneading, $0.3 \%$ of additive and $54.8 \%$ of water, with temperature of $8-10{ }^{\circ} \mathrm{C}$. Dough was mixed in a high-speed spiral mixer MS-6 for $4 \mathrm{~min}$, whereby an optimum temperature of the dough for puff pastry production was achieved $\left(19 \pm 1{ }^{\circ} \mathrm{C}\right)$. Afterwards, the dough was subjected to relaxation for 10 min and then thinned on a laminator Laminoir Marchand LA4-500. The margarine samples ML1 and ML2 were sheeted and placed into the dough sheet according to English method (McGill, 1981) in an amount of 30,40 and $50 \%$ on flour weight.

During lamination the thickness of dough was progressively reduced to $8 \mathrm{~mm}$, folded by one three-fold $(1 \times 3)$ or fourths $(1 \times 4)$ and re-rolled to $8 \mathrm{~mm}$. After repeated folding procedures, the dough was submitted to relaxation between the lamination for $15 \mathrm{~min}$ at $8-10{ }^{\circ} \mathrm{C}$. These procedures were repeated twice, resulting in the formation of 108, 144 and 256 fat layers. The final thickness of laminated dough was formed by the progressive reduction of its thickness: $30 \rightarrow 28 \rightarrow 25 \rightarrow$ $22 \rightarrow 18 \rightarrow 15 \rightarrow 12 \rightarrow 10 \mathrm{~mm}$. Dough pieces in circular shape with a diameter $D_{0}$ $=56 \pm 1 \mathrm{~mm}$, height $\mathrm{H}_{0}=10 \pm 1 \mathrm{~mm}$ and $\mathrm{a}$ weight of $30 \pm 1 \mathrm{~g}$ were baked in a laboratory oven at $200-210{ }^{\circ} \mathrm{C}, 15-20$ minutes.

\section{Physical characteristics and sensory quality of puff pastry}

Hardness of puff pastry was defined by measuring the surface under obtained curve of Force (g) - Time (s) dependence $2 \mathrm{~h}$ after baking. The force required to cut pastry was measured on the Texture Analyzer TA.HDPlus with the following operating parameters: load cell - $25 \mathrm{~kg}$, speed of the knife before the measurement $-1.0 \mathrm{~mm} / \mathrm{s}$, speed of the knife during the measurement $-2.0 \mathrm{~mm} / \mathrm{s}$, speed of the knife after the measurement $10.0 \mathrm{~mm} / \mathrm{s}$, the distance of knife from the platform - $55 \mathrm{~mm}$, cutting force $-5.0 \mathrm{~g}$.

The sensory quality was defined two hours after baking by a point-based method. Three-member panel by rating from 1 to 5 evaluated the following quality parameters of puff pastry: external appearance, texture, taste and odour. Obtained evaluations of mentioned parameters were multiplied by certain coefficient of importance (ISO, 2008b) and on the basis of the total sum of obtained points, the quality category was determined: excellent (17.620.0); very good (15.2-17.5); good (13.2$15.1)$; acceptable (11.2-13.1) and unacceptable $(<11.2)$. Using scores from 0 to 3 , the crumb quality of puff pastry was evaluated according to the QDA method (Hozová et al., 2002). The evaluated parameters were following: flakiness, flakiness uniformity, thickness of pore walls, pore size and color uniformity.

\section{RESULTS AND DISCUSSION}

\section{Characteristics of puff pastry margarines}

Fat phase of puff pastry margarines contains from 30 to $55 \%$ of saturated fatty 
acids (SAFA) and trans fatty acids from < $1 \%$ up to $25 \%$ (Šoronja-Simović, 2012), while a satisfactory consistency of margarine provides either the presence of SAFA or TFA in margarine fat phase (Karlović, 1983; Nielsen, 2006). By the analysis of margarine fat phase, the increase in the content of SAFA in regards to the traditional puff pastry margarine was noticed (ML1 42.3\%, ML2 50.9\%) (Table 1). Both samples were characterized by reduced content of TFA, but there were significant differences: in the margarine sample ML1 TFA content was $6.1 \%$, while in ML2 it was negligible $(<1 \%)$. Despite the low proportion of TFA due to the high share of certain saturated fatty acids in margarine samples, total content of SAFA + TFA was about $50 \%$, which is common in margarines with high content of transisomers. In sample ML2, the share of monounsaturated fatty acids (MUFA) was higher by $2 \%$, while the share of polyunsaturated fatty acids (PUFA) was lower by $5 \%$, in comparison to ML1.

The plastic properties of margarine samples were determined measuring the solid fat content (SFC). The results showed that both margarine samples had a higher content of solid triglycerides than the value defined as the area of plasticity at temperatures of 20,25 and $30{ }^{\circ} \mathrm{C}$. According to Stauffer (1996) in temperature interval between 10 and $30{ }^{\circ} \mathrm{C}$ the solids content should be at 10 to $25 \%$. At temperatures important for puff pastry processing (20 and $25^{\circ} \mathrm{C}$ ) SFC values for sample ML2 were $20-35 \%$ higher compared to the sample ML1 (Table 1). Also, the sample ML2 had more stable solid to liquid phase ratio than ML1 sample in the entire temperature range.

The melting point of both margarine samples was in the interval typical for most special-purpose margarines (McGill, 1981). It can be expected that the margarine ML2 will have better technological characteristics because its $\mathrm{Tt}$ is in the interval between $42-44{ }^{\circ} \mathrm{C}$ (Table 1). Such margarines provide good stability of continuous margarine layers. On the other hand, margarine ML1 had a slightly lower melting point $\left(39{ }^{\circ} \mathrm{C}\right)$ and it is expected that this sample will have better sensory, but worse technological characteristics (McGill, 1981; Šoronja-Simović, 2012). Change in melting enthalpy in ML2 margarine was higher by $25 \%$ compared to margarine ML1. Based on literature data (de Man et al., 1991; Laia et al., 2000), the obtained results indicate that in margarine ML1 the present primary and secondary bonds in fat crystal network are weaker than in sample ML2.

Differences in hardness of ML1 and ML2 margarine at temperatures of 10, 20 and $30{ }^{\circ} \mathrm{C}$ (Table 1) were the consequence of different SFC, whereas the ability of body to resist deformation is determined by the content and the composition of solid fat fraction (Stauffer, 1996). The hardness of sample ML1 at storage temperature (10 $\left.{ }^{\circ} \mathrm{C}\right)$ was relatively low, because the literature data (Šoronja Simović, 2010) indi-

Table 1.

Comparison of ML1 and ML2 margarine samples characteristics

\begin{tabular}{llcc}
\hline & & ML1 & ML2 \\
\hline Farameters & & & \\
\hline & SAFA & 42.3 & 50.9 \\
\multirow{5}{*}{ Solid fat content (\%) } & MUFA & 33.2 & 35.4 \\
& PUFA & 18.4 & 13.6 \\
& $\mathrm{TFA}$ & 6.1 & 0.2 \\
Thermal characteristics & $20^{\circ} \mathrm{C}$ & 31.6 & 40.0 \\
& $25^{\circ} \mathrm{C}$ & 21.7 & 33.0 \\
Hardness $(\mathrm{g})$ & $30^{\circ} \mathrm{C}$ & 14.6 & 27.5 \\
& $\mathrm{Tt}\left({ }^{\circ} \mathrm{C}\right)$ & 39.0 & 43.4 \\
& $\Delta \mathrm{Ht}(\mathrm{J} / \mathrm{g})$ & 20.1 & 25.2 \\
& $10^{\circ} \mathrm{C}$ & 860.7 & 1144.7 \\
& $20^{\circ} \mathrm{C}$ & 156.1 & 339.8 \\
\hline
\end{tabular}

SAFA - saturated fatty acids, MUFA - monounsaturated fatty acids, PUFA - polyunsaturated fatty acids, Tt melting temperature, $\Delta H t$ - change in melting enthalpy 
cate that the value of mentioned parameter in puff pastry margarine is usually in the range of 1000 to as much as $2500 \mathrm{~g}$. Margarine hardness at $20{ }^{\circ} \mathrm{C}$ is important from the aspect of choice of puff pastry margarine, because mentioned temperature is the optimum for the dough preparation and the stability of dough/margarine layers (McGill, 1981; Cauvain and Young, 2001). At $20{ }^{\circ} \mathrm{C}$ comes to a significant reduction in hardness of both samples (ML1 up to $80 \%$, ML2 by $70 \%$ ) and the hardness for sample ML1 is much lower than the recommended value of about $400 \mathrm{~g}$ (Šoronja Simović, 2010). By increasing the temperature from 20 to $25{ }^{\circ} \mathrm{C}$ the changes in hardness of margarine ML2 were less pronounced, which indicated that this should not significantly affect the laminating process at room temperature.

\section{Puff pastry quality}

The most of the assumptions that were obtained by examination of physico-chemical characteristics of margarine were confirmed by the results of evaluation of puff pastry sensory quality. The lift of pastry samples with margarine ML1 was far below the optimal theoretical interval (Table 2). Cauvain and Young (2001) point out that for properly formed layered structure of puff pastry the height of the dough during baking should be increased from 6 to 8 times.

A slight increase in lift as a function of the number of margarine layers by 5 to $20 \%$ was noticed, whereby these effects were the most evident in samples with $40 \%$ of margarine ML1. The increase of the amount of margarine had more pronounced positive effect on the pastry lift. The changes were at the level of 45 to $65 \%$ and were the most evident in samples with 256 layers of margarine (Table 2). It is assumed that the insufficient lift in pastries with ML1 margarine was the consequence of its low hardness at 20 and $25^{\circ} \mathrm{C}$, making it difficult for lamination and probably caused the sticking of layers of dough. The disruption of continuous dough-fat film did not provide the retention of water vapor in layers of margarine and resulted in the absence of a significant increase in pastry height (Cauvain and Young, 2001).

The volume of a large number of samples was less than $75 \mathrm{~cm}^{3}$, which is below the satisfactory levels that would ensure optimal quality of puff pastry. Even though, a positive effect on volume was noticed by increased amount of margarine. The highest values for this parameter were obtained with puff pastry with $50 \%$ of margarine and 144 layers. The mentioned sample had greater volume in average by 20 to $25 \%$ compared to the volume of the samples with 30 and $40 \%$ of margarine at the same number of layers (Table 2). Low lift did not have a drastic consequence on the puff pastry firmness. The increase of number of margarine layers from 108 to 256 increased the pastry firmness by $45 \%$.

Table 2.

Effects of margarine ML1 on puff pastry characteristics

\begin{tabular}{lccccl}
\hline $\begin{array}{l}\mathbf{x} \\
(\%)\end{array}$ & $\mathbf{y}$ & Lift & $\begin{array}{c}\text { Volume } \\
\left(\mathbf{c m}^{\mathbf{3}}\right)\end{array}$ & $\begin{array}{c}\text { Firmness } \\
\mathbf{( k g s )}\end{array}$ & Quality category \\
\hline 30 & 108 & $1.9 \pm 0.3$ & $51.1 \pm 0.2$ & $15.6 \pm 2.2$ & $10.3-$ unacceptable \\
& 144 & $2.3 \pm 0.2$ & $66.5 \pm 0.4$ & $27.3 \pm 3.2$ & $12.6-$ acceptable \\
& 256 & $1.9 \pm 1.1$ & $56.7 \pm 0.9$ & $28.3 \pm 1.3$ & $10.9-$ unacceptable \\
\hline 40 & 108 & $2.1 \pm 0.6$ & $56.0 \pm 0.6$ & $14.9 \pm 3.7$ & $13.7-$ good \\
& 144 & $2.4 \pm 0.8$ & $63.7 \pm 0.5$ & $25.5 \pm 1.0$ & $14.3-$ good \\
& 256 & $2.7 \pm 0.2$ & $73.8 \pm 0.4$ & $27.5 \pm 4.1$ & $12.5-$ acceptable \\
\hline 50 & 108 & $2.8 \pm 0.1$ & $77.6 \pm 0.1$ & $14.5 \pm 8.2$ & $15.8-$ very good \\
& 144 & $2.9 \pm 1.2$ & $83.5 \pm 0.8$ & $17.7 \pm 1.3$ & $14.8-$ good \\
& 256 & $3.2 \pm 0.5$ & $71.8 \pm 0.6$ & $25.8 \pm 4.1$ & $12.6-$ acceptable \\
\hline
\end{tabular}

$x$ - quantity of margarine ( $\mathrm{g} / 100 \mathrm{~g}$ flour)

** number of margarine layers 
A positive effect on the firmness of puff pastry had the amount of margarine, i.e., it led to its reduction. The minimum firmness of $14.5 \mathrm{kgs}$ was obtained in the sample with $50 \%$ of margarine and 108 margarine layers.

The results of sensory evaluation of puff pastry showed that only the sample with the highest content of margarine ML1 and 108 margarine layers belonged to very good quality category (Table 2 ).

In addition, in the case of pastry samples with $30 \%$ of margarine only by the formation of 144 margarine layers acceptable quality can be achieved, while other samples in terms of sensory quality are unacceptable.
The results of QDA method of sensory evaluation shown in Figure 1 indicate that the addition of 30 and $40 \%$ of margarine $M L 1$, regardless of the number of margarine layers, cannot ensure the formation of the layered and delicate structure of pastries.

This confirms the previous conclusions that margarine ML1 does not have proper physico-chemical properties for production of puff pastry.

Only $50 \%$ of margarine in combination of dough folding which includes the formation of 144 fat layers can provide moderate, partially uniform flakiness and partially uniform color.

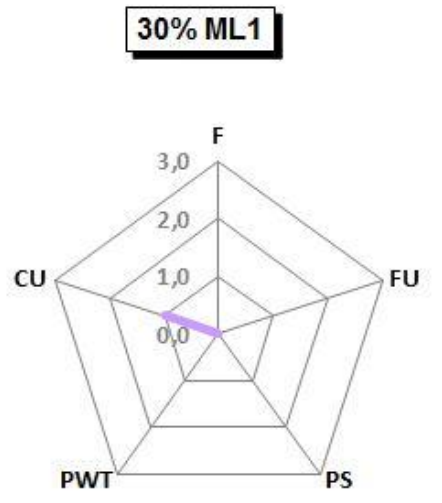

108 layers

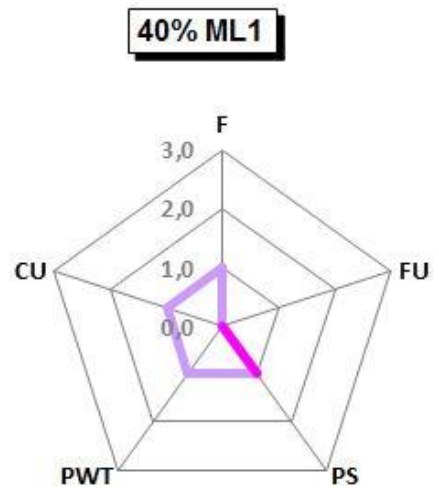

144 layers
$50 \%$ ML1

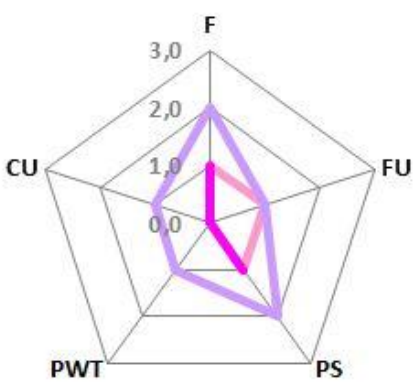

256 layers

Figure 1. QDA chart of puff pastry with margarine ML1

F - flakiness, FU - flakiness uniformity, PS - pore size, PWT - pores wall thickness, CU - color uniformity

Table 3.

Effects of margarine ML2 on puff pastry characteristics

\begin{tabular}{llcccl}
\hline $\begin{array}{l}\mathbf{x} \\
(\%)\end{array}$ & $\mathbf{y}^{* *}$ & Lift & $\begin{array}{c}\text { Volume } \\
\left(\mathbf{c m}^{\mathbf{3}}\right)\end{array}$ & $\begin{array}{c}\text { Firmness } \\
(\mathbf{k g s})\end{array}$ & Quality category \\
\hline 30 & 108 & $3.6 \pm 0.2$ & $87.1 \pm 0.1$ & $36.1 \pm 4.3$ & $15.9-$ very good \\
& 144 & $3.9 \pm 0.8$ & $94.3 \pm 0.6$ & $40.7 \pm 4.8$ & $14.2-$ good \\
& 256 & $2.6 \pm 0.2$ & $71.7 \pm 0.2$ & $38.9 \pm 3.9$ & $13.8-$ good \\
\hline 40 & 108 & $4.2 \pm 0.3$ & $100.0 \pm 0.5$ & $20.0 \pm 5.2$ & $16.4-$ very good \\
& 144 & $4.3 \pm 0.6$ & $97.3 \pm 0.9$ & $21.2 \pm 4.2$ & $15.9-$ very good \\
& 256 & $2.8 \pm 1.1$ & $69.5 \pm 1.0$ & $31.7 \pm 4.8$ & $14.3-$ good \\
\hline 50 & 108 & $4.1 \pm 0.7$ & $102.5 \pm 0.5$ & $16.5 \pm 1.4$ & $15.9-$ very good \\
& 144 & $3.4 \pm 0.1$ & $78.6 \pm 0.3$ & $18.4 \pm 2.6$ & $15.7-$ very good \\
& 256 & $5.1 \pm 0.3$ & $112.4 \pm 0.3$ & $29.5 \pm 3.9$ & $19.0-$ excellent \\
\hline
\end{tabular}

$x$ - quantity of margarine $(g / 100 \mathrm{~g}$ flour)

${ }^{* *} y$ - number of margarine layers 
Changes in physical properties of pastry as a function of the quantity of margarine ML2 and the number of formed margarine layers are shown in Table 3 . The results indicate that samples with margarine ML2 have better lift in comparison with pastries with ML1. It is assumed that this is caused by higher hardness and higher SFC of margarine ML2 at 20 and $25^{\circ} \mathrm{C}$.

In the majority of samples the lift was above 3.5 and the maximum value of this parameter of 5.1 was obtained in samples with 50\% margarine ML2 and with 256 layers of margarine. The consequence of good lift was also good and very good volume of samples, wherein the maximum volume was obtained in the aforementioned pastry sample. This sample had around $45 \%$ higher volume compared to samples with $30 \%$ and $40 \%$ of margarine with the same number of margarine layers (Table 3).

The firmness of pastry with ML2 margarine in $50 \%$ of samples exceeded the maximal firmness obtained for pastry with margarine ML1. In comparison with ML1 pastry samples, ML2 samples had about $40 \%$ higher firmness. Despite higher firmness of samples with $50 \%$ of margarine and 256 margarine layers $(29.5 \mathrm{kgs})$, they belonged to the quality category excellent (Table 3).
Sensory quality of samples with margarine ML2 was much better compared to the samples with ML1. In the samples with ML2 margarine the layered structure was more pronounced, the layers were much thinner and the flakiness was uniform. The mentioned layers affected the taste of final product. Puff pastry with ML1 had poor mouth melting characteristic compared to the ML2 sample. Moreover, the corresponding sample also had fatty aftertaste.

By the QDA method of sensory evaluation the previously obtained results were confirmed. The samples with $40 \%$ of margarine and 108 and 144 margarine layers had a very good sensory quality. In the sample with maximal amount of margarine and margarine layers maximum scores were achieved, i.e., excellent flakiness, small thickness and uniformity of pore walls, large pores and uniform color (Figure 2).

Comparing the best puff pastry samples (50\% ML1 and 144 layers; 50\% ML2 and 256 layers) it can be seen that the physical properties and sensory quality of pastry with margarine ML2 were much better. Volume of rolls is increased by $25 \%$ and lift up to $45 \%$ compared to the sample with margarine ML1 (Figure 3).

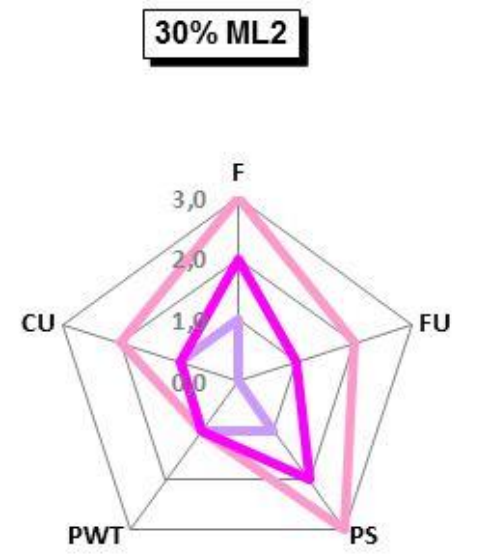

108 layers

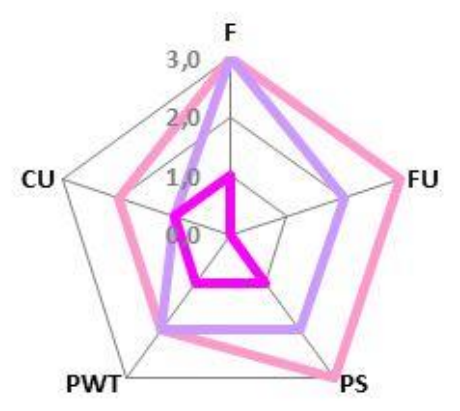

144 layers

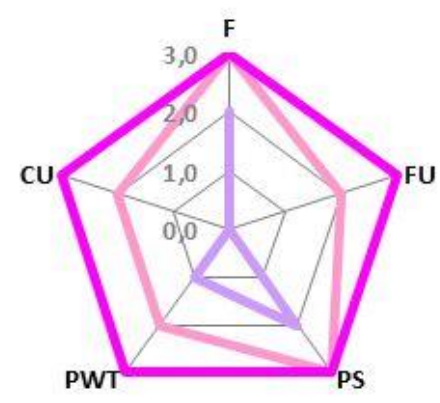

256 layers

Figure 2. QDA chart of puff pastry with margarine ML2

F - flakiness, FU - flakiness uniformity, PS - pore size, PWT - pores wall thickness, CU - color uniformity 

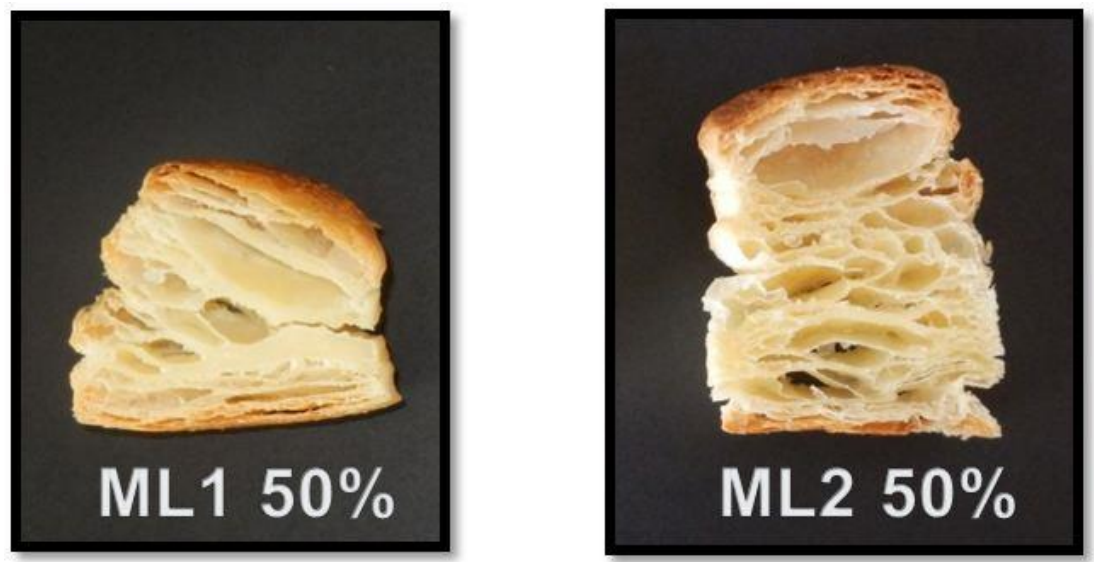

Figure 3. Effect of the margarine type on the quality of puff pastry

\section{CONCLUSIONS}

Based on the results of investigation of the possibilities for application of puff pastry margarines with reduced trans fatty acids for puff pastry production the importance of selection of margarine with appropriate technological characteristics must be emphasized, in order to obtain a product of good quality. Only by application of the maximum amount of margarine ML1 and 144 margarine layers a satisfactory quality of puff pastry was obtained. For mentioned values of independent parameters the lift of 2.89 , hardness of $17.7 \mathrm{kgs}$, volume of $83.6 \mathrm{~cm}^{3}$ and the total number of points of 14.8 was achieved.

Based on the obtained results for properties of two margarine samples, we can conclude that higher stability of formed fat layers can be provided by application of ML2 margarine in puff pastry production. Lower hardness of ML1 margarine by 50 $60 \%$ compared to the margarine ML2 caused its embedding in dough structure. Moreover, lower SFC of sample ML1 by $20-35 \%$ and worse thermal characteristics in comparison to ML2 disabled formation of stable margarine-dough layers, i.e., characteristic crumb appearance of pastry. Thus, the physico-chemical properties of margarine ML1 were not optimal for puff pastry production. Significantly better physical properties and excellent pastry quality was obtained in the samples with margarine ML2 in an amount of $50 \%$ margarine and 256 layers: the higher lift by $45 \%$, volume by $25 \%$ and the total number of points by about $20 \%$ were achieved compared to ML1 sample with the best quality.

However, with the addition of $40 \%$ of margarine ML2 high volume of about 100 $\mathrm{cm}^{3}$, lower firmness of about $20 \mathrm{kgs}$ and very good sensory quality can be obtained. Very good sensory quality was obtained in the sample with $30 \%$ of ML2 and 108 formed layers, which is extremely important from the aspect of improving the nutritional profile and energy density of puff pastry.

\section{ACKNOWLEDGEMENTS}

This study was supported by the Provincial Secretariat for Higher Education and Scientific Research, Project No. 114-4512085/2016.

\section{REFERENCES}

1. AACC (1995). Approved Methods of the American Association of Cereal Chemists, 9th Ed., AACC Inc., St Paul, MN, AACC methods 44-9, 46-12 and 54-21.

2. Aro, A. (2006). The scientific basis for trans fatty acid regulations - Is it sufficient?: A European perspective. Atherosclerosis Supplements, 7 (2), 67-68.

3. Cauvain, S.P., Young, L.S. (2001). Bakery Food Manufacture and Quality: Water Control and Effects, Blackwell Science, Oxford, UK.

4. de Man, L., de Man, J.M., Blackman, B. (1991). Physical and textural characteristics of some North American shortenings. Journal of American Oil Chemists Society, 68 (2), 63-69.

5. Hozová, B., Kukurová, I., Turicová, R., Dodok, L. (2002). Sensory quality of stored croissanttype bakery products. Czech Journal of Food Sciences, 20 (3), 105-112.

6. ISO (2002). International Organization for Standardization. Determination of the content of 
trans fatty acid isomers of vegetable fats and oils - Gas chromatographic method, ISO 15304.

7. ISO (2008a). International Organization for Standardization. Determination of the solid fat content by pulsed nuclear magnetic resonance method, ISO 8292-1.

8. ISO (2008b). International Organization for Standardization. Sensory analysis, ISO 8586-2.

9. Karlović, Đ. (1983). Razrada tehnološkog postupka interesterifikacije radi dobijanja unapred utvrđenih fizičkih i funkcionalnih osobina masti, PhD Thesis, Faculty of Technology, Novi Sad, Serbia.

10. Kritchevsky, D. (2008). Fats and oils in human health. In Food Lipids: Chemistry, Nutrition, and Biotechnology. Eds. C.C. Akoh, D.B. Min, CRC Press, New York, pp. 690-695.

11. Laia, O.M., Ghazalia, H.M., Cho, F., Chong, C L. (2000). Physical and textural properties of an experimental table margarine prepared from lipase-catalysed transesterified palm stearin: palm kernel olein mixture during storage. Food Chemistry, 71, 173-179.
12. Mc Gill, E.A. (1981). A closer look at bakery fats. In Puff Pastry Faults. Ed. E. A. McGill, Peerless, Food Products, Liverpool, p. 14.

13. Nielsen, K. (2006). Is the quality and cost of food affected if industrially produced trans fatty acids are removed? Atherosclerosis Supplements, 7 (2), 61-62.

14. Stauffer, C.E. (1996). Fats and Oils, American Association of Cereal Chemists, St. Paul, Minnesota.

15. Šoronja Simović, D. (2010). Uticaj sastava masne faze margarina na fizičke osobine i kvalitet peciva od laminiranog testa, $P h D$ Thesis, Faculty of Technology, Novi Sad, Serbia.

16. Šoronja-Simović, D. (2012). Nutritivna vrednost lisnatog peciva. Andrejević Foundation, Belgrade and Faculty of Technology, Novi Sad, Serbia.

17. (WHO) World Health Organization (2003). Technical Report Series, No. 894: Diet, nutrition and the prevention of chronic diseases, Report of a Joint WHO/FAO Expert Consultation. World Health Organization, Geneva.

\section{УТИЦАЈ КОЛИЧИНЕ И БРОЈА СЛОЈЕВА МАРГАРИНА СА СНИЖЕНИМ САДРЖАЈЕМ ТРАНС МАСНИХ КИСЕЛИНА НА КВАЛИТЕТ ЛИСНАТОГ ПЕЦИВА}

Јана Ј. Захорец ${ }^{* 1}$, Драгана М. Шороња-Симовић ${ }^{1}$, Зита И. Шереш ${ }^{1}$, Оливера Д. Шимурина ${ }^{2}$, Анастасија И. Селаковић ${ }^{3}$, Никола Р. Маравић ${ }^{1}$, Бојана В. Филипчев ${ }^{2}$

${ }^{1}$ Универзитет у Новом Саду, Технолошки фракултет у Новом Саду, 21000 Нови Сад, Булевар цара Лазара 1, Србија

${ }^{2}$ Универзитет у Новом Саду, Научни институт за прехрамбене технологије у Новом Саду, 21000 Нови Сад, Булевар цара Лазара 1, Србија

${ }^{3}$ МиниПани доо, 24000 Суботица, Хиподромска бб, Србија

Сажетак: Циљ овог рада је да се на бази резултата одређивања физичких и сензорских особина лиснатог пецива испита утицај маргарина за ламинирање сниженог садржаја транс изомера у изради лиснатог пецива побољшане нутритивне вредности. Експерименти су планирани на основу фракторског плана $3^{2}$, при чему су независно променљиве количина маргарина за ламинирање (30, 40 и 50\%, на масу брашна) и број формираних слојева током обраде теста $(108,144$ и 256). У циљу одређивања оптималне вредности независних параметара, испитивања су фокусирана на дефинисање релевантних квалитативних показатеља готовог производа.

Испитивањем утицаја врсте маргарина за ламинирање (ML1 и ML2) на квалитет лиснатог пецива, показало се да физичко-хемијске особине маргарина ML1 нису оптималне за израду лиснатог пецива. Маргарин ML1 има за 50-60\% нижу вредност тврдоће, за 20-35\% нижи садржај чврстих триглицерида и лошије топлотне карактеристике у поређењу са маргарином ML2. Искључиво апликацијом максималне количине маргарина ML1 и 144 слојева масти постигнут је релативно добар квалитет лиснатог пецива: нарастање 2.89, тврдоћа 17.7 кгс, запремина 83.6 цм ${ }^{3}$ и збир бодова 14.8. Због бољих технолошких карактеристика, маргарин ML2 је повољнији за производњу лиснатог пецива. Значајно боље фризичке особине и одличан сензорски квалитет пецива добијен је код узорака са 50\% маргарина ML2 и 256 слојева: веће нарастање за $45 \%$, запремина за $25 \%$ и укупан број бодова за око $20 \%$ у поређењу са набољим узорцима са маргарином ML1.

Кључне речи: транс масне киселине, лиснато пециво, сензорски квалитет, текстурна својства 